\title{
MENINGKATKAN KEMAMPUAN MOTORIK KASAR ANAK USIA DINI MELALUI KREATIFITAS SENI
}

\author{
Friska Indah Septiani ${ }^{1}$, Wulan Purnama ${ }^{2}$, Agus Sumitra ${ }^{3}$ \\ ${ }^{1}$ RA Baitussalam, J1. Pojok Selatan 1 Rt 02 Rw 07 \\ ${ }^{2}$ RA Nurul Anam, Kp. Cigombong Rt 02 Rw 05 Desa Sukamulya Kec. Cipongkor KBB \\ ${ }^{3}$ IKIP Siliwangi Bandung, Jl. Terusan Jenderal Sudirman, Cimahi \\ 달.ska.indahs@yahoo.com, ${ }^{2}$ wulanp612@gmail.com, ${ }^{3}$ agussumitra@ikipsiliwangi.ac.id
}

\begin{abstract}
The background that encourages this research is the gross motoric development of children has not shown a positive development. It seems that children tend to be passive do not want to imitate the movements exemplified by the teacher. overall. This study aims to determine (1) gross motor capacity before performing artistic creativity (2) gross motor capacity when carrying out artistic creativity (3) gross motor capacity after performing artistic creativity. The type of research conducted is Classroom Action Research (CAR) with research subjects aged 5-6 years as many as 25 children. The object of this research is to improve gross motor. Research was conducted by means of classroom action research methods with a model with kemmis and taggart which included planning, implementation, observation and reflection. The results showed that artistic creativity was able to develop gross motor skills, this was evident from the average score of gross motor skills when the initial conditions were before the action amounted to $61.15 \%$ which means an increase of $21.94 \%$ after the action. It can be concluded that the use of artistic creativity can improve the gross motoric of children aged 5-6 years in RA. Baitussalam. Therefore, it can be said that gross motoric children can be improved through artistic creativity. Input that can be put forward from this research is that artistic creativity can be used as an alternative teacher in teaching.
\end{abstract}

Keywords: $\quad$ Rough Motoric, Art Creativity

\begin{abstract}
Abstrak
Latar belakang yang mendorong riset ini adalah pengembangan motorik kasar anak belum menunjukan perkembangan yang positif.Hal ini terlihat anak cenderung pasif tidak mau menirukan gerakan-gerakan yang dicontohkan oleh pengajar., Walapun guru sudah melakukan berbagai upaya, namun upaya tersebut belum mampu meningkatkan motorik kasar secara menyeluruh.Penelitian ini bertujuan untuk mengetahui (1) kapasitas motorik kasar sebelum melakukan kreatifitas seni (2) kapasitas motorik kasar ketika melaksanakan kreatifitas seni (3) kapasitas motorik kasar setelah melakukan kreatifitas seni.Jenis risetyang dilakukan adalah Penelitian Tindakan Kelas (PTK) dengan subjek penelitiananak umur 5-6 tahun sebanyak25 anak. Objek riset ini adalah meningkatkan motorik kasar. Riset dilakukan dengan cara metode penelitian tindakan kelas dengan model dengan kemmis dan taggart yang meliputi perencanaan, pelaksanaan, observasi dan refleksi.Hasil penelitian menunjukkan bahwa kreatifitas senimampu mengembangkan motorik kasar, hal ini terlihat dari rata-rata skor kemampuan motorik kasar saatkondisi awal sebelum tindakan sebesar $61,15 \%$ yang berartimeningkat sebesar 21,94\% setelah tindakan.Dapat disimpulkan bahwa penggunaan kreatifitas seni dapat meningkatkan motorik kasar anak usia 5-6 tahun di RA.Baitussalam.Oleh sebab itu, bisa dikatakan motorik kasar anak dapat ditingkatkan melalui kegiatan kreatifitas seni. Masukan yang bisa dikemukakan dari riset ini yaitu supaya kegiatan kreatifitas seni dapat digunakan sebagai salah satu alternatif guru dalam mengajar.
\end{abstract}

Kata Kunci: Motorik Kasar, Kreatifitas Seni

\section{PENDAHULUAN}

Masa anak-anak merupakan waktu yang relatif panjang bagi anak-anak untuk belajar tentang segala hal. Anak usia 4 sampai dengan 6 tahun merupakan usia peniru yang handal yang harus di manfaatkan secara optimal untuk mendapatkan stimulus pembelajaran agar 


\section{JURNAL GERIA}

ISSN : 2614-6347 (Print) 2614-4107 (Online)

\begin{tabular}{l|l|l} 
Vol.2 & No.3 & Mei 2019 \\
\hline
\end{tabular}

semua aspek perkembangan anak bisa berkembang dengan maksimal (Cucu, Wiwin \& Agus). Oleh sebab itu sangat dibutuhkan rangsangan pembelajaran yang sesuai dengan tahapan usia anak. Agar dapat menjadi wadah untuk pengembangan potensi dan bakat yang dimiliki anak. Dalam kurun waktu tersebut mereka menjalani cara perkembangan di semua aspek antara lain perkembangan jasmani, kognitif, mental, sosial, perkembangan emosional, maupun perkembangan moral. Anak memiliki banyak potensi pada masing-masing bentuk perkembangan tersebut. Agar dapat menumbuhkan bakat setiap anak, diperlukan fasilitas berupa pendidikan yang tepat sebagai wadahnya. Pendidikan ini tidak semata pendidikan secara formal saja, namun juga termasuk didalamnya adalah pendidikan dalam keluarga, pendidikan dalam masyarakat, dan tentunya pendidikan secara formal pada suatu lembaga pendidikan.

Realita di sekolah khususnya di RA Baitussalam Bandung menunjukan bahwa pengembangan motorik kasar yang dilaksanakan belum optimal. Masalah itu bisa diketahui pada saat anak melaksanakanmotorik kasar di pagi hari, masih terdapat anak yang mengalami kesulitan, cenderung pasif tidak mau menirukan gerakan yang dicontohkan oleh guru, walaupun guru sudah melakukan berbagai upaya,

namun upaya tersebut belum mampu

meningkatkan motorik kasar secara menyeluruh. Kurangnyakeinginan dalam mengikuti gerak guru.

Anak kurang memahami gerakan yang $\mathrm{s}$ udah di contohkan. Meskipun guru sudah melakukan berbagai upayamelalui beberapa kegiatan namun upaya tersebut belum mampu menungkatkan motorik kasar secara menyeluruh karena masih terlihat anak tidak melaksanakan aktifitas motorik kasar.

Hal tersebut dikarenakan kurangnya latih an melalui kegiatan motorik kasar yang dapat menarik minat anak untuk mengikuti kegiatan dan anak cenderung merasa bosan ketika hanya kegiatan motorik kasar itu saja yang diulangulang.

Ada beragam teknik untuk mengembangkan motorik kasar, diantaranya melalui kreatifitas seni yang menarik.Kreatifitas seni yang menarik dapat merangsang anak untuk menggerakan tubuhnya sehingga dapat menimbulkan semangat anak untuk bergerak dan akan memungkinkan interaksi langsung antara anak didik dengan guru. Motorik kasar yaitu gerakan fisik yang melibatkan seluruh anggota tubuh dan otot-otot besar pada anak untuk melakukan aktivitas.Kreatifitas Seni adalah cara guru menerapkan kegiatan yang melibatkan seluruh anggota tubuh untuk bergerak, seperti kepala, tangan, kaki dan badan. Jadi dengan menggunakan kreatifitas seni, anak dapat bebas menggerakan anggota tubuh dan dapat menjadikan anak senang dan antusias dalam mengikutinya.

\section{Motorik Kasar}

Menurut Saputra dan Rudyanto (2005:117) "motorik kasar ialah kemampuan anak beraktivitas dengan menggunakan otot-otot besarnya".Sedangkan pendapat dari Sujiono (2010: 1.13) "motorik kasar adalah kemampuan yang membutuhkan koordinasi sebagian besar tubuh anak". Oleh karena itu, biasanya memerlukan tenaga karena dilakukan oleh otot-otot yang lebih besar.Gerakan motorik kasar melibatkan aktivitas otot tangan,kaki,dan seluruh tubuh anak.Gerakan ini mengandalkan kematangan dan koordinasi.

Suyadi (2009:176) "gerak motorik kasar adalah gerak anggota badan secara kasar atau keras".Menurut Berk (dalam Suyadi, 2009:176) semakin anak bertambah dewasa dan kuat tubuhnya, maka gaya geraknya semakin sempurna.Hal ini mengakibatkan tumbuh kembangnya otot semakin membesar dan menguat.Dengan membesar dan menguatnya otot tersebut, keterampilan baru selalu bermunculan dan semakin bertambah kompleks. Sedangkan menurut Riva (2012:15) motorik kasar adalah kemampuan yang berhubungan dengan 


\section{JURNAL GERIA}

ISSN : 2614-6347 (Print) 2614-4107 (Online)

\begin{tabular}{l|l|l} 
Vol.2 & No.3 & Mei 2019 \\
\hline
\end{tabular}

menggerakkan tubuh secara penuh, contoh: berlari, memanjat, melompat, dan lain-lain.

Berdasarkan beberapa pendapat di atas, dapat disimpulkan bahwa motorik kasar adalah aktivitas gerak fisik yang membutuhkan koordinasi anggota tubuh dengan menggunakan kinerja otot-otot besarnya, misal: berjalan, berlompat, merangkak, dan mengayunkan tangan.

Meningkatkan kemampuan motorik anak saat mereka di usia AUD membuat aktifitas fisik atau motorik mereka juga semakin banyak.Tak heran jika anak-anak Usia Dini gemar sekali bermain tanpa mengenal lelah.Segala kegiatan anak selalu dilakukan dengan bermain. Bermain akanmeningkatkan aktifitas anak. Maxim (1993) "menyatakan bahwa aktivitas fisik akanmeningkatkan pula rasa keingintahuan anak dan membuat anak-anak akan memperhatikan benda-benda untuk dapat menangkapnya, mencoba melemparkannya atau menjatuhkannya, mengambil, menggosok-gosok, dan meletakan kembali benda-benda kedalam tempatnya".

Perkembangan motorik kasar merupakan perkembangan anak menggunakan seluruh anggota badan (otot otot besar) untuk melakukan sesuatu. Pada masa kanak-kanak perkembangan fisik terjadi pada semua bagian tubuh dan fungsinya.Seperti perkembangan kemampuan motoriknya, khususnya motorik kasarnya yangberupa kemampuan mengubah beragam posisi tubuh dengan menggunakan otot - otot besar. Berikut ini dijelaskan mengenai perkembangan motorik kasar anak usia dini yaitu:

Menurut Sujiono dkk (2010) perkembangan kronologis, motorik kasar usia lima tahun dan enam tahun yaitu:

1. Berlari dan langsung menendang bola.

2. Melompat-lompat dengan kaki bergantian.

3. Melambungkan bola tenis denga n satu tangan dan menangkapnya deng an dua tangan.

4. Berjalan pada garis yang sudah ditentukan.

5. Berjinjit dengan tangan dipinggul.
6. Menyentuh jari kaki tanpa menekuk lutut.

7. Mengayuhkan satu kaki kedepan atau kebelakang tanpa kehilangan keseimbangan.

Menurut Walkey dalam Bambang Sujiono dkk, karakteristik perkembangan motorik kasar pada anak usia 4-5 tahun yaitu:

a) Mengekspresikan gerak tari dengan irama sederhana.

b) Berjalan dengan baik (keseimbangan tubuh makin baik).

c) Berlari dengan baik (keseimbangan tubuh makin baik).

d) Berlari di tempat.

e) Naik turun tangga tanpa berpegangan.

f) Melompat dengan satu kaki bergantian.

g) Merayap dan merangkak lurus ke depan.

h) Senam mengikuti contoh.

i) Berjalan di atas papan titian (keseimbangan tubuh).

j) Berjalan dengan berbagai variasi (maju mundur di atas satu garis).

k) Memanjat dan bergelantungan (berayun).

1) Melompati parit atau guling.

Selanjutnya Didith mengemukakan perkembangan fisik motorik kasar anak usia dini adalah sebagai berikut:

1) Usia 4 Tahun

a) Memiliki kontrol untuk berhenti memulai atau berputar yang lebih efektif.

b) Dapat melompat dengan jaraklompatan 24 ke 33 inci.

c) Dapat menuruni tangga deng an menggunakan satu kaki secara berulang, jika dibantu.

d) Dapat melompat satu kaki sampai enam kali.

2) Usia 5 Tahun

a) Dapat memulai berbalik dan berhenti secara efektif dalam permainan. 


\section{JURNAL GERIA}

ISSN : 2614-6347 (Print) 2614-4107 (Online)

\begin{tabular}{l|l|l} 
Vol.2 & No.3 & Mei 2019
\end{tabular}

b) Dapat melompat dengan berlari dengan jarak lompatan 28 sampai 36 inci.

c) Dapat menuruni tangga panjang dengan satu kaki secara berulang tanpa bantuan.

d) Dapat melompat sampai 16 kaki dengan mudah. ${ }^{24}$

Feeny (dalam Yus, 2010) juga mengemukakan mengenai perkembangan fisik motorik kasar anak usia dini pada masa Preschool yaitu:

a) Berjalan dengan tangan terayun.

b) Berlari dengan seimbang dan dapat berhenti secara tiba - tiba.

c) Melompat untuk menjangkau be nda keatas atau kedepan.

d) Mengayuh sepeda dengan cepat.

e) Menangkap dan melempar bola dengan cepat.

Sit (2015) juga mengemukakan dalam bukunya Psikologi Perkembangan Anak Usia Dini mengenai perkembangan kemampuan motorik kasar anak usia dini usia 4-6 tahun adalah sebagai berikut:

a. Berjalan dengan berbagai gerakan;

b. Mencari jejak;

c. Berjalan seperti binatang;

d. Berjalan naik turun tangga;

e. Berbaris, melangkah, berjinjit, berjalan seperti gerakan binatang;

f. Berlari dengan membawa benda;

g. Berjalan ditempat;

h. Senam;

i. Bermain Outdor;

j. Menggulung badan;

k. Memanjat tiang panjatan;

1. Bergelayut;

m. Melompat dengan tepat dan melangkah dengan irama;

n. Berjalan dengan papan titian maju, mundur, dan ke samping;

o. Berdiri di lingkaran dan berputar dengan musik;

p. Menirukan lompatan binatang;

q. Melompat dengan membawa bendabenda kecil;

r. Mencangklong

s. Hula hop

t. Bergantung; u. Menari;

v. Menyapu

w. Meloncat

x. Menendang, melempar, dan menangkap bola atau benda lain.

Maka dari beberapa uraian diatas peneliti dapat simpukan bahwa perkembangan motorik anak usia dini berbeda-beda menurut tingkat jenis tahun perkembangannya.

\section{KREATIFITAS SENI}

\section{Perkembangan Kreativitas atau Daya Cipta}

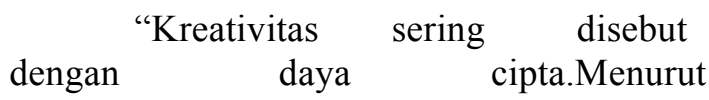
Freeman dan Munandar (dalam Slamet Suyanto, 2005:75), kreativitas sama halnya dengan aspek psikologi lainnya hendaknya sudah berkembang sedini mungkin semenjak anak dilahirkan".

Menurut Danasee (2013), pengertian kreativitas secara umun adalah bagian dari kegiatan berproduksi atau berkarya.

\section{Pengertian Kreativitas Seni}

Menurut Sumanto (2005: 11), kreativitas seni adalah bagian dari kegiatan berproduksi at au ber-karya seni termasuk dalam bidang senirupa.

Menurut Elliot (dalam Suratno, 2005: 24), "menyatakan bahwa kreativitas seni sangat dekat dengan imajinasi atau manifestasi kecerdikan dalam pencarian yang bernilai".Sedangkan ahli lain Supriadi yang dikutip oleh Rachmawati \& Kurniati (2010: 13),"mengutarakan bahwa kreativitas adalah kemampuan seseorang untuk melahirkansesuatu yang baru, baik berupa gagasan maupun karya nyata yang relatif berbeda dengan apa yang telah ada". Dari beberapa pengertian yang disampaikan di atas, dapat disimpulkan bahwa kreativitas seni adalah sesuatu yang dihadapi anak usia dini dalam menyelesaikan permasalahan (problem solving) dengan sebaik apapun sehingga anak mampu meyelesaikan masalah yang 


\section{JURNAL GERIA}

ISSN : 2614-6347 (Print) 2614-4107 (Online)

Vol.2 2 No.3 1 Mei 2019

dihadapinya dengan baik.

Munandar (dalam Sumanto, 2005:

39), "mengatakan bahwa kreativitas seni merupakan pengalaman dalam mengekspresikan dan mengaktualisasikan identitas individu dalam bentuk terpadu antara hubungan diri sendiri, alam, dan orang lain". Pada umumnya definisi kreativitas dirumuskan dalam istilah pribadi (person), proses (process), produk (product), dan dorongan (press), seperti diungkapkan oleh Rhodes yang menyebutkan sebagai "Four P's of Creativity: Person, Process, Product, and Press.

Dari pengertian atau definisi kreativitas di atas dapat dijabarkan bahwa:

a. Person (segi pribadi), kreativitas adalah hasil keunikan pribadi dalam interaksinya dengan lingkungan dan merupakan penggambaran adanya berbagai ciri khusus dalam tiap individu. Cirinya antara lain berupa rasa ingin tahu, daya imajinasi kuat, tertarik pada hal-hal yang baru, mempunyai minat yang luas, berani mengambil resiko, mempunyai prakasa dan kepercayaan diri, tekun dan ulet dalam mengerjakan tugas yang diminati dan diyakini.

b. Process (segi proses), kreativitas adalah hasil dari tahapan pengalaman seseorang dalam melakukan suatu pekerjaan atau kegiatan.

c. Product (segi produk), kreativitas adalah kemampuan untuk mencipta atau menghasilkan produk-produk baru, atau kombinasi dari hal sebelumnya yang sudah ada. Jika kondisi pribadi anak dan kondisi lingkungan cukup mendukung, maka akan memungkinkan seseorang untuk menghasilkan suatu produk kreatif.

d. Press (segi pendorong), merupakan suatu kondisi yang memotivasi seseorang pada perilaku kreatif. Pendorong kreativitas ini dapat berupa keinginan yang kuat pada diri individu, dan dapat juga berupa penghargaan dari orang lain (orang tua, guru), serta tersedianya sarana dan prasarana penunjang sikap kreatif. Menurut Suratno (2005: 40), terdapat dua faktor pendukung kemauan seseorang, yaitu kemauan dari dalam (motivasi intrinsik) dan kemauan yang disebabkan karena dorongan dari luar (motivasi ekstrinsik).

Dari beberapa uraian definisi di atas, penulis dapat menyimpulkan bahwa kreativitas merupakan suatu proses seseorang yang memiliki gagasan atau idebaru, proses baru, produk yang baru yang muncul dari kesadaran diri danmenghasilkan penghargaan atas kreasi baik itu penghargaan dari dirinya sendiri maupun penghargaan dari orang lain.

Dari beberapa pedapat diatas dapat disimpulkan bahwa kreativitas seni adalah kemampuan berkarya seni dengan memanfaatkan imajinasinya dan kemampuannya untuk berkreativitas sehingga mampu menemukan, menciptakan atau memadukan ke dalam suatu karya seni rupa yang indah dan menarik.

\section{Ciri kreativitas seni}

$$
\text { Menurut Supriadi (dalam }
$$

Rachmawati \& Kurniati, 2010:13), mengatakan bahwa ciri-ciri kreativitas seni dapat dikelompokkan dalam dua kategori, kognitif, dan nonkognitif. Ciri kognitif diantaranya originalitas (keaslian), fleksibilitas (fleksibel atau keluwesan), fluency (kelancaran), dan elaborasi (menguraikan).Sedangkan ciri nonkognitif diantaranya motivasi sikap dan kepribadian kreatif.Kedua ciri ini sangatlah penting dan saling berkaitan seperti yang disampaikan oleh Rachmawati, \& Kurniati, (2010:15), bahwa kecerdasan yang tidak ditunjang dengan kepribadian kreatif tidak menghasilkan apapun.Kreativitas seni dalam penelitian ini adalah kreativitas anak dalam berkreasi membentuk bebas terarah dengan menggunakan plastisin.

Dari pendapat di atas, seorang anak yang kreatif akan memiliki kemampuan dan fluency atau kelancaran untuk menghasilkan ide baru atau cara berpikir baru, sehingga anak kreatif tersebut mampu menyelesaikan masalah yang dihadapinya (problem solving). Sedangkan fleksibilitas atau keluwesan diartikan bahwa seorang anak yang kreatif memiliki banyak ide dan mengembangkannya 


\section{JURNAL GERIA}

ISSN : 2614-6347 (Print) 2614-4107 (Online)

Vol.2 2 No.3 1 Mei 2019

dalamkesehariannya, bahkan dapat memecahkan permasalahan yang rumit. Originalitasatau keaslian lebih dilihat dari segi kemampuan untuk menghasilkan ide yang unik dalam arti berbeda dengan orang lain, sedangkan elaboration atau menguraikan adalah anak mampu menjelaskan atau menyampaikan hasil tersebut.

Anak kreatif memiliki rasa ingin tahu yang tinggi serta ingin memuaskan keingintahuannya itu sebelum akhirnya mampu menghasilkan produk secara kreatif pula.

Menurut Suratno (2005: 10), "anak kreatif adalah anak yang mampu memperdayakan pikirannya untuk menghasilkan gagasan baru, memecahkan masalah dan ide yang mempunyai maksud dan tujuan yang ditentukan".

\section{Kondisi Yang Dapat Meningkatkan Kreativitas Seni Anak Usia Dini}

Kreativitas merupakan unsur bawaan yang hanya dimiliki oleh sebagian kecil anak yang akan berkembang secara otomatis dan membutuhkan banyak rangsangan atau dorongan dari lingkungan sekitar. Menurut Harlock (1978: 11), kondisi yang meningkatkan kreativitas antara lain: a) waktu, b) kesempatan menyendiri, c) dorongan, d) sarana, e) lingkungan yang merangsang, f) hubungan orang tua dan anak yang tidak posesif, g) cara mendidik anak, dan h) kesempatan untuk memperoleh pengetahuan.

Dari pendapat tersebut dapat diuraikan bahwa untuk menjadi kreatif, anak sebaiknya diberikan waktu untuk berkreasi dan diberikan juga kebebasan untuk mengembangkan kreativitasnya atau dengan cara lain yaitu memberikan anak kesempatan untuk menyendiri sesaat untuk mengembangkan imajinasinya. Sebagai pendidik maupun orang tua memberikan dorongan berupa stimulus,memberikan sarana yang mendukung untuk bereksperimen dan bereksplorasi,lingkungan yang mendukung sangatlah penting, karena dengan semangat dan dorongan yang diberikan akan membuat anak tersebut lebih percaya diri. Selain itu adanya kesempatan serta hubungan yang baik antara anak dan orang tua serta cara mendidik yang demokratis dan permisif akan menumbuhkan kreatifitas dan yang lebih penting adalah menumbuhkan rasa percaya diri yang tinggi.

\section{Kondisi Yang Dapat Merugikan Kreativitas Seni Anak Usia Dini}

Selain kondisi yang menguntungkan ada juga kondisi yang merugikan kreativitas anak usia dini. Pendapat ini disampaikan oleh Hurlock (1978: 11), antar lain sebagai berikut: a) membatasi eksplorasi, b) keterpaduan waktu , c) dorongan kebersamaan keluarga, d) membatasi khayalan, e) peralatan bermain yang sangat terkstruktur, f) orang tua yang terlalu melindungi, dan g) disiplin yang otoriter.

Dari pendapat tersebut dapat dijabarkan bahwa kondisi di lingkungan sekitar juga bisa merugikan kreativitas anak, seperti membatasi anak untuk bereksplorasi, hal ini diartikan bahwa dengan membatasi anak untuk berekplorasi maka orang tua juga membatasi perkembangan kreativitas anak.Keterpaduan waktu tersebut diartikan apabila anak serba diatur sehingga hanya tersisa sedikit waktu untuk bebas bermain sesuka hati. Maksud dorongan kebersamaan keluarga diartikan bahwa apabila semua keluarga melakukan kegiatan secara bersamasama tanpa memperdulikan minat dan pilihan masing-masing individu, kemudian dengan peralatan yang sangat terstruktur, contohnya adalah mainan boneka yang sudah berpakaian lengkap tanpa ada asesoris untuk melengkapinya (tas, topi, baju ganti,dan lainlain).

bagi $\begin{gathered}\text { Pertumbuhan otak } \\ \text { perkembangan }\end{gathered} \begin{gathered}\text { sangat penting } \\ \text { fisik,kognitif, }\end{gathered}$ dan emosional pada individu (Papalia, Old, \& Feldman, 2008; Mutiah, 2010).Tidak diragukan lagi bahwa otak merupakan pusat kecerdasan. Otak berfungsi untuk berpikir, mengontrol emosi,

dan mengkoordinasikan aktivitas tubuh (Suyanto, 2005). Dengan demikian, jika kita mampu memahami perkembangan otak manusia, maka kita akan mampu untuk memahami perkembangan yang terjadi pada manusia yang pada akhirnya dapat 


\section{JURNAL GERIA}

ISSN : 2614-6347 (Print) 2614-4107 (Online)

Vol.2 2 No.3 1 Mei 2019

membantu untuk mengoptimalkan segala potensiyang ada pada diri individu. Demikian pula pentingnya

memahami perkembangan otak pada anak usia dini, sehingga nantinya kita akan dapat memahami upaya-upaya yang dapat mengoptimalkan segala potensi yang ada pada aud.

Otak pada individu mulai berkembang secara gradual pada usia sekitar dua minggu setelah pembuahan, berkembang dari tabung panjang menjadi sekelompok sel berbentuk bulat (Santrock, 2002; Papalia, Old,\&Feldman, 2008). Sembilan bulan kemudian, bayi lahir dengan otak dan sistem syaraf yang berisi hampir 100 milyar sel syaraf (Santrock, 2002; Papalia,Old,\& Feldman, 2008; Kledon, 2006; Mutiah, 2010). Otak bayi itu sudah berisi hampir semua sel syaraf (neurons) yang akan dimiliki sepanjang kehidupannya. Namun, pola penyambungan antara sel-sel itu masih harus dimantapkan karena pada saat lahir dan pada masa awal bayi keterkaitan sel-sel syaraf ini masih lemah (Santrock,2002; Kledon, 2006). Kledon (2006) pun memaparkan, bahwa sebelum lahir, kegiatan neuronlah yang berperan memperhalus jaringan Tetapi setelah lahir, kegiatan neuron itu tidak spontan lagi, dan tugas memperhalus jaringan itu digerakkan oleh banjir pengalaman inder a.

Pada saat lahir, berat otak individu hanya sekitar $25 \%$ dari berat otak dewasa, dan pada tahun kedua, otak bayi yang baru lahir sekitar 75\% dari berat otak dewasanya (Santrock, 2002; Papalia, Old, \&Feldman,2008; Kledon, 2006). Pada usia enam tahun, ukuran otak hampir sebesar otak orang dewasa, tapi pertumbuhan dan perkembangan fungsi bagian spesifik dari otak terus berlanjut hingga dewasa (Papalia,Old,\&Feldman,2008).

Sebagaimana yang disampaikan oleh Kledon (2006), bahwa banyaknya jumlah sambungan tersebut mempengaruhi kualitas kemampuan otak sepanjang hidupnya, dimana kualitas kemampuan otak dalam menyerap dan mengolah informasi tergantung dari banyaknya neuron yang membentuk unit- unit pada jaringan syaraf diotak. Jumlah hubungan antar sel syaraf otak tersebut sangat ditentukan oleh rangsangan dan makanan.

Berdasarkan penjelasan yang sudah dipaparkan diatas, maka dapat dipahami bahwa pendekatan perkembangan otak menjadi perhatian penting dalam pengasuhan dan pengembangan anak usia dini karena seperti yang sudah diketahui sebelumnya bahwa otak memegang kendali dalam kehidupan seorang manusia. Kledon (2006) menjelaskan bahwa saat paling menentukan bagi perkembangan otak itu terjadi pada usia 0-3tahun. Sebagaimana yang dijelaskan pula oleh Papalia, Old \& Feldman (2008) bahwa pertumbuhan pesat otak yang dimulai sekitar trimester ketiga dalam kehamilan dan terus berlanjut hingga paling tidak usia 4 tahun merupakan hal yang penting bagi perkembangan fungsi syaraf. Dari semua itu, pengalaman di usia dini berkontribusi besar terhadap struktur dan kapasitas otak individu.

\section{HASIL DAN PEMBAHASAN}

HASIL

Penelitian tindakan kelas ini dilaksanakan di RA Baitussalam Bandung, dalam penelitian teknik pengumpulan data merupakan suatu hal yang sangat penting dalam setiap penelitian, karena dari hasil pengumpulan data ini akan menentukan pengelolaan sehingga mendapatkan kesimpulan.

Teknik pengumpulan data dalam penelitian ini menggunakan teknik non tes yang berupa observasi dan dokumentasi. Untuk mempermudah dalam melaksanakan analisis hasil lembar observasi, maka peneliti membuat nilai sebagai berikut :

\begin{tabular}{|c|c|c|c|}
\hline Nomor & Tanda & Skor & $\begin{array}{c}\text { Keter } \\
\text { angan }\end{array}$ \\
\hline 1. & $\bullet$ & $\mathbf{3}$ & Baik \\
\hline 2. & $\sqrt{ }$ & $\mathbf{2}$ & Cuku \\
\hline 3. & 0 & $\mathbf{1}$ & Kuran \\
\hline & & & $\mathbf{g}$ \\
\hline
\end{tabular}

Tabel 1.1 analisis hasil observasi) 


\section{JURNAL GERIA}

ISSN : 2614-6347 (Print) 2614-4107 (Online)

\begin{tabular}{l|l|l} 
Vol.2 & No.3 & Mei 2019 \\
\hline
\end{tabular}

Keterangan :

1. Baik (3) apabila anak dapat melakukan metode gerak dan lagu dengan baik sehingga anak mempunyai kemampuan motorik kasar baik

2. Cukup (2) apabila anak melakukan metode gerak dan lagu masih terlihat cukup baik sehingga anak mempunyai kemampuan motorik kasar cukup

3. Kurang (1) apabila anak belum bisa melakukan metode gerak dan lagu dengan baik sehingga anak mempunyai kemampuan motorik kasar kurang.

Data-data tersebut dianalisis mulai dari siklus satu dan siklus dua untuk dibandingkan perolehan nilai rataratanya.Hasil perhitungan dikonsultasikan dengan tabel deskriptif prosentasi, yang dikelompokan dalam 3 kategori, yaitu baik, cukup, kurang sebagai berikut :

\begin{tabular}{|c|c|c|}
\hline $\begin{array}{c}\text { Krite } \\
\text { ria }\end{array}$ & $\begin{array}{c}\text { Skor } \\
\text { Peroleh } \\
\text { an }\end{array}$ & Penafsiran \\
\hline Baik & $80-100$ & $\begin{array}{c}\text { Peningkatan motorik kasar } \\
\text { anak baik }\end{array}$ \\
\hline $\begin{array}{c}\text { Cuku } \\
\text { p }\end{array}$ & $54-79$ & $\begin{array}{c}\text { Peningkatan motorik } \\
\text { kasar anak cukup }\end{array}$ \\
\hline Kuran & $<53$ & $\begin{array}{c}\text { Peningkatan motorik } \\
\text { kasar anak kurang }\end{array}$ \\
\hline g & & \\
\hline
\end{tabular}

Tabel 1.2 deskriptif hasil observasi

Berdasarkan penelitian menunjukkan bahwa metode kreatifitas seni lebih diminati anak dibandingkan dengan kegiatan yang sering dilakukan anak setiap harinya untuk meningkatkan motorik kasar anak di RA BAITUSSALAM Bandung, guru membuat perencanaan kreativitas seni yang lebih menarik dan menyenangkan.Hal ini dilakukan agar anak dapat menerima kegiatan dengan maksimal.Guru mengajak anak untuk melakukan kegiatan kreatifitas seni agar anak dapat menerima kegiatan motorik kasar dengan maksimal. Hal ini dapat dilihat anak lebih senang dan bersemangat, serta menumbuhkan rasa percaya diri anak.

Pada pelaksanaan guru dalam mengondisikan anak sebelum kegiatan dimulai sudah baik secara menyeluruh, dalam mempersiapkan media, dalam menyampaikan kegiatan kreatifitas Seni dapat diterima anak dengan baik, dalam penyampaian tujuan kegiatan sesuai dengan indikator yang dituangkan dalam bentuk RKH (Rencana Kegiatan Harian). Hampir seluruh anak aktif dalam mengikuti kegiatan sehingga dapat mencapai hasil yang cukup maksimal.

Peningkatan motorik kasar anak melalui kreatifitas seni tersajikan dalam tabel berikut ini:

\begin{tabular}{|l|c|c|c|}
\hline $\begin{array}{l}\text { N } \\
\text { o }\end{array}$ & Keterangan & $\begin{array}{c}\text { Kondisi } \\
\text { Awal }\end{array}$ & $\begin{array}{c}\text { Kondisi } \\
\text { Akhir }\end{array}$ \\
\hline 1 & Ketuntasan & $\begin{array}{c}61,15 \\
\%\end{array}$ & $83,09 \%$ \\
\hline & & & \\
\hline 2 & Peningkatan & - & Berhasil \\
\hline & \multicolumn{3}{|l}{} \\
\hline Tabel 1.3 peningkatan hasil motorik kasar \\
anak
\end{tabular}

Berdasarkan tabel di atas peningkatan motorik kasar anak terhadap hasil metode Kretifitas Seni peningkatan prosentase terhadap peningkatan motorik kasar anak pada kondisi awal dan kondisi akhir dapat digambarkan dengan grafik dibawah ini:

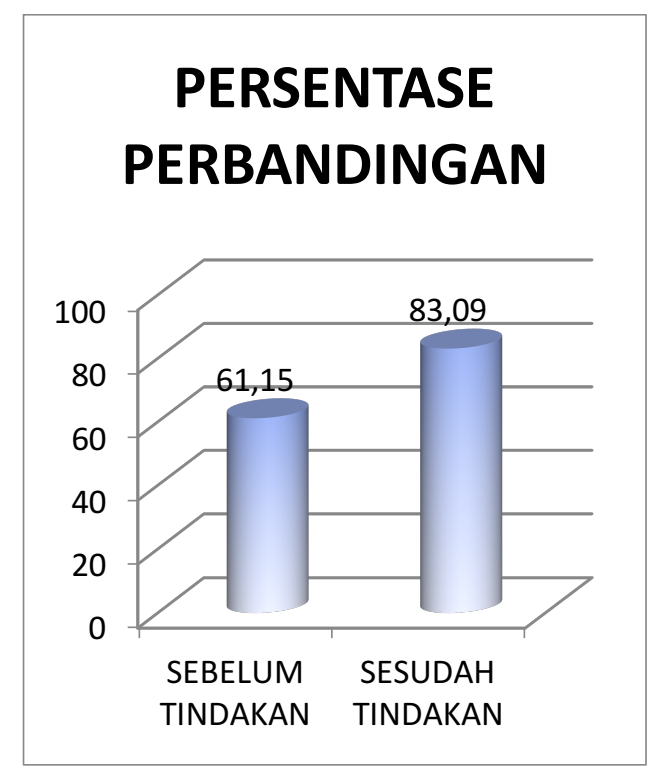

Diagram 1.1 persentase kreativitas motorik kasar 


\section{JURNAL GERIA}

ISSN : 2614-6347 (Print) 2614-4107 (Online)

\begin{tabular}{l|l|l} 
Vol.2 & No.3 & Mei 2019 \\
\hline
\end{tabular}

Secara umum dapat disimpulkan
bahwa Kreatifitas Seni dapat
meningkatkan motorik kasar anak di RA
Baitussalam Bandung Tahun Ajaran
2018/2019.

\section{PEMBAHASAN}

Seperti yang sudah dikemukakan sebelumnya, bahwa agar perkembangan motorik kasar anak berkembang secara optimal maka pendidik dan orangtua harus dapat menyesuaikan dan menstimulus untuk mengembangkan motorik kasar anak.

Berikut ini akan disampaikan beberapa upaya yang dilakukan oleh pendidik agar dapat mengoptimalkan perkembangan motorik kasar anak melalui teori Dave (dalam Suyadi, 2010).

1. Imitation (Peniruan)

Imitation adalah keterampilan untuk menentukan suatu gerakan yang telah dilatih sebelumnya. Latihan ini bisa dengan cara mendengarkan atau memperlihatkan. Dengan demikian, kemampuan ini merupakan reprentasi ulang terhadap apa yang dilihat dan didengar anak.

2. Manipulation (Penggunaan Konsep)

\section{Manipulation}

adalah kemampuan untuk

menggunakan konsep dalam

melakukan kegiatan. Kemampuan

ini juga sering

disebut sebagai kemampuan manip ulasi.Sebab, pada tahap ini

perkembangan anak

selalu mengikuti arahan,

penampakan gerakan-gerakan,

dan menetapkan suatu

keterampilan gerak tertentu

berdasarkan latihan.

3. Presition (Ketelitian)

Presition adalah kemampuan yang

berkaitan dengan gerak

mengindikasikan tingkat

4. Articulation (Perangkaian)

Articulation adalah kemampuan

untuk melakukan serangkaian

gerakan secara

kombinatif dan berkesinambungan.

5. Naturalization

(Kewajaran/Kealamiahan)

Naturalization adalah kemampuan

untuk melakukan gerak

secara wajar atau luwes.

Kemampuan motorik kasar dengan kreativitas seni adalah bagian dari kegiatan yang berproduksi agar tetap memadukan kegiatan antara motorik kasar dan kreativitas seni. Selain itu motorik kasar juga berfungsi untuk meningkatkan perkembangan gerak anggota badan secara kasar atau keras.Sedangkan kreativitas seni diartikan

sebagai kemampuan menemukan, menciptakan, membuat, merancang ulang, dan memadukan kedalam komposisi suatu karya seni dengan didukung kemampuan terampilyang dimilikinya.

\section{KESIMPULAN}

Berdasarkan hasil penelitian tinda kan kelas dalam keseluruhan pembahasan dan analis dapat disimpulkan bahwa Kreatifitas Seni dapat meningkatkan motorik kasar anak usia di ni di RA Baitussalam Tahun Ajaran 2018/2019. Hal tersebut dapat ditandai dengan melihat dari kondisi awal anak dengan hasil nilai hasil rata-rata anak dengan prosentase hasil belajar anak 61,15\%. Kemudian kondisi setelah tindakan dengan prosentase hasil belajar anak 21,94\% sehingga dapat dikatakan ada peningkatan pada hasil belajar anak dengan prosentase meningkat menjadi 83,09\%. 


\section{DAFTAR PUSTAKA}

Danasee. (2013). Perkembangan Kreativitas Anak Usia Dini. Diakses dari http://danasee.blogspot.com/2013/ 03 perkembangan_kreativitas_anak_u sia_dini.html.pada tanggal 2 Agustus 2018, Jam 10.16 WIB.

Hurlock, E. B. (1978) Perkembangan Anak Jilid 1 Edisi keenam.terjemahan oleh Meitasari Tjandrasa dan Muslichah Zarkasih. Jakarta: Erlangga.

Mutiah, D. (2010). Psikologi Bermain Anak Usia Dini. Jakarta: Kencana Prenada Media Group.

P Ambara, Didith. (2014). Asesmen Anak Usia Dini. Yogyakarta: Graha Ilmu.

Rachmawati, Y., \& Kurniati, E. (2010).

Strategi Pengembangan Kreativitas Pada Anak Usia Taman KanakKanak. Jakarta: Kencana Prenada Mecia Group.

Riva, I. (2012). Koleksi Games Edukatif di Dalam dan Luar Sekolah. Yogyakarta: Flash Book Rosmala.
Saputra, Y. M., \& Rudyanto. (2005). Pembelajaran Kooperatif untuk Meningkatkan Keterampilan Anak TK. Jakarta: Departemen Pendidikan Nasional.

Sit, M. (2015). Psikologi Perkembangan Anak Usia Dini Jilid I, Medan: Perdana Publishing.

Sujiono, B dkk. (2010). Metode Pengembangan Fisik, Cet.13. Jakarta: Universitas Terbuka.

Sumanto. (2005). Pengembangan Kreativitas Seni Rupa Anak TK, Jakarta: Departemen Pendidikan Nasional.

Suratno. (2005). Pengembangan Kreativitas Anak Usia Dini. Jakarta: Departemen Pendidikan Nasional.

Suyadi, (2009). Bimbingan Konseling Untuk PAUD. Yogjakarta: Diva Press.

Suyadi, (2010). Psikologi Belajar PAUD. Yogyakarta: PT Bintang Pusaka Abadi (BiPA)

Yus, A. (2010). Penilaian Perkembangan Belajar Anak. Medan: Kencana. 